\title{
Ecological structure and carbon storage in traditional silvopastoral systems in Nicaragua
}

\author{
Aura Cárdenas · Ana Moliner • Chiquinquirá Hontoria · Muhammad Ibrahim
}

\begin{abstract}
Forests and agroforestry systems in the tropics play a decisive role in global carbon fixation strategies. The amount and type of coverage, along with the specific land use and land use change in a given area, determines whether carbon is stored or released into the atmosphere. The aim of this study was to evaluate the traditional silvopastoral systems (TSPS) through quantitative analysis of biomass and soil carbon storage whilst simultaneously qualitatively determining the ecological structure in terms of tree richness and diversity. The study was carried out in Matiguás, a sub-humid tropical region of Nicaragua, on five land use types: shrubland; intervened secondary forest; pasture with high tree density; pasture with low tree density and degraded pasture. Biomass carbon was estimated by allometric equations and soil organic carbon was evaluated at four depths $(0-10$, $10-20,20-40$ and $40-100 \mathrm{~cm}$ ). Of the land uses studied, shrubland had the highest diversity. The biomass carbon ranged from 1.9 to $13.2 \mathrm{t} \mathrm{C} \mathrm{ha}^{-1}$ for degraded pasture and intervened secondary forest, respectively. The highest soil organic carbon (SOC) storage at $1 \mathrm{~m}$ depth was for intervened secondary
\end{abstract}

forest (163 $\mathrm{t} \mathrm{C} \mathrm{ha}^{-1}$ ), whereas degraded pastures had the lowest value $\left(76 \mathrm{t} \mathrm{C} \mathrm{ha}^{-1}\right)$. Since SOC was the largest pool of total carbon in all cases, it should be evaluated down to a depth of at least $1 \mathrm{~m}$. Increasing tree coverage in degraded and low-tree density pastures can contribute not only to enhance carbon sequestration but also to restore degraded lands in livestock landscapes.

Keywords Pastures - Carbon sequestration · Land use change $\cdot$ Sub humid tropical conditions $\cdot$ Soil organic carbon

\section{Introduction}

Between 1990 and 2015, around 200 million ha of tropical forest were lost through natural and anthropogenic drivers, such as fire, drought, clearance for agriculture and infrastructure development (Keenan et al. 2015). In the case of Latin America, large areas of tropical forest cover have been deforested and converted to extensive cattle raising over the past decade (Graesser et al. 2015). This conversion of forests to cropland and the expansion of pastureland are associated with the global demand for food, feed and fuel (Gibbs et al. 2010). In Central America, pastureland and cropland constitutes a major land use/land cover (LULC) category, increasing by $40 \%$ approximately from 1961 to 2001 (Carr et al. 2006). 
Tropical forests store greater amounts of carbon than other ecosystems (Chaturvedi et al. 2011), therefore land use changes with the conversion of forest to agricultural systems have a significant impact on global greenhouse gas emissions (IPCC 2007). The transformation of natural ecosystems releases $\mathrm{CO}_{2}$ stored in the vegetative biomass and soil into the atmosphere; the amount released determined by the quantity of carbon stored in woody vegetation and soil organic matter (West et al. 2010).

According to the Global Forest Resources Assessment 2000 (FAO 2001), Nicaragua has 6.2 million ha of forest. Of those, 1.8 million ha are assigned to conservation and 4.4 million ha are productive forest. The advancing agricultural frontier and cattle raising has consumed 1.8 million ha of forest. In recent years, the total amount of pastureland in Nicaragua grew from 0.8 million ha in 1950 to 4.2 million ha in 1997 (Szott et al. 2000), largely as a result of the clearcutting of forest areas. This land use change represents an ongoing environmental degradation (McGroddy et al. 2015; Kaimowitz 1996), reducing the regional biodiversity, contributing to water pollution and increasing the emission of greenhouse gases, such as methane $\left(\mathrm{CH}_{4}\right)$ and carbon dioxide $\left(\mathrm{CO}_{2}\right)$ to the atmosphere (Bennetzen et al. 2016).

Traditional silvopastoral systems (TSPS) are defined as the integration of trees and shrubs in pastures with animals for economic, ecological and social sustainability (Montagnini et al. 2013). They are a better alternative to conventional pasture, due to their greater capacity for carbon sequestration (McGroddy et al. 2015) and global warming mitigation (IPCC 2000; Andrade and Ibrahim 2003) as well as for biodiversity conservation (Jose 2009). However, TSPS have been poorly studied, especially in tropical areas under sub humid conditions. Our study aimed to determine the ecological structure of various TSPS while at the same time assessing the contribution to total carbon storage of both above and belowground biomass as well as soil organic carbon (SOC) in Nicaragua. This research, therefore, contributes to the information required for decision-making regarding the most adequate land use change strategies for improving climate change mitigation and the recovery of degraded lands.

Following this introduction, the second section describes the geographical characteristics of study area and explains the methodologies used for selecting land use classes and establishing sampling plots for each land use. The ecological structural analysis, assessment of above and belowground biomass, the estimation of soil organic carbon and the statistical analysis applied are also discussed in "Materials and methods" section. The third section presents the results of the different analyses outlined in the second section and, finally, a comprehensive discussion of the key results and conclusions are provided.

\section{Materials and methods}

\section{Study area}

The research took place in the municipality of Matiguás $\left(12^{\circ} 50^{\prime} \mathrm{N} / 85^{\circ} 27^{\prime} \mathrm{O}\right)$, longitude East and altitude between 200 and $500 \mathrm{~m}$ above sea level. It covers $1710 \mathrm{~km}^{2}$ and is Located in the department of Matagalpa in North Central Nicaragua, one of the largest cattle raising regions of the country. The prevailing climate is sub-humid tropical with mean annual temperatures between 28 and $32{ }^{\circ} \mathrm{C}$ and an annual rainfall from 1200 to $2000 \mathrm{~mm}$ (Levard et al. 2001; Yamamoto et al. 2007). According the KöppenGeiger climate classification (Kottek et al. 2006), this climate is classified as "tropical wet and dry or savannah climate" (Aw). The annual rainy season in Matiguás lasts from May until December, with a dry period from January until April. Vertisol is the predominant soil order in the area. The landscape is characterized by the predominance of natural and improved pastures, with trees. There are also patches of primary, secondary and riparian forests (Ruiz et al. 2004).

\section{Selection of land use/land cover (LULC) classes}

In the initial phase of the study, LULC classes were chosen according to their representativeness following two-staged approach. In the first stage, geographical data of the research area (e.g., orthophotos, satellite imagery, soil and vegetation maps) were analyzed in a Geographical Information System (GIS) for identifying the LULC classes (Andrade and Ibrahim 2003). In the second stage, the identified classes were groundtruthed by a field survey. Overall twenty-three land LULC classes were identified, from which five classes were selected based on their significance for land 
degradation trends and their representativeness in the area (Pagiola et al. 2007) (Table 1).

\section{Experimental design}

Four replicates of each one of the five land uses were randomly selected comprising twenty sampling areas, which were located in small to large size livestock farms from Matiguás municipality. In each of these areas, three sampling points, separated $50 \mathrm{~m}$ from each other along the slope were selected. Sampling strategies for biomass or soil carbon were centered around these sampling points.

Plots for estimation of biomass and ecological structure in pastureland were selected following a methodology suggested by MacDicken (1997). Circular plots of $1000 \mathrm{~m}^{2}$ centered in the previous selected points were stablished, resulting in a total of $3000 \mathrm{~m}^{2}$ sampled in each replicate. With respect to plots for intervened secondary forest and shrubland, an adaptation of the methodology proposed by Segura and Kanninen (2002) was selected. These plots consisted of rectangular areas of $25 \mathrm{~m} \times 10 \mathrm{~m}$ centered on the previous chosen points, with the longest length along the slope (Fig. 1).

With respect to sampling for soil carbon analyses there was one principal trial pit $(1 \mathrm{~m} \times 1 \mathrm{~m} \times 1 \mathrm{~m})$ located in each point and two small trial pits $(0.4 \mathrm{~m} \times 0.4 \mathrm{~m} \times 0.4 \mathrm{~m})$ on either side of the principal pit. Each principal pit was spaced $50 \mathrm{~m}$ from its nearest neighbor, while the small pits were spaced $15 \mathrm{~m}$ from the corresponding principal pit (Fig. 1).
Ecological structure analysis

A forest inventory was developed for each land use in order to evaluate the ecological structure and estimate the carbon storage associated with the above and belowground biomass. The species of every tree with a DBH (diameter at breast height) greater than $5 \mathrm{~cm}$, saplings $(<1.5 \mathrm{~m}$ high and $\mathrm{DBH}<4.9 \mathrm{~cm})$ and seedlings ( $0.3-1.5 \mathrm{~m}$ high) were identified.

The basal area (BA) was estimated using the following equation:

$\mathrm{BA}=0.00007854 \times \mathrm{DBH}^{2}$

and the tree density was calculated as the number of individuals per ha. Rarefaction curves have been implemented to estimate the richness distribution for the land uses studied (Krebs 1989). Furthermore, the Margalef (1958) index was calculated to assess the diversity of species for the different land uses:

$\mathrm{R}=(\mathrm{S}-1) / \ln \mathrm{N}$

where $\mathrm{S}$ is the number of taxa, and $\mathrm{N}$ is the number of individuals in the sample. The Margalef index refers to values below 2.0 as low-diversity areas and values above 5.0 as indicative of high biodiversity (Margalef 1958).

In addition, Fisher's alpha diversity index was chosen to estimate diversity because of its ability to discriminate information, its relative sample size sensitivity, and robustness (Magurran 1981). Fisher's alpha diversity index (Fisher et al. 1943) was calculated as:

Table 1 LULC classes of traditional silvopastoral system selected in the study area according to their representativeness

\begin{tabular}{|c|c|c|}
\hline Land use & Symbol & Description \\
\hline Shrubland & SL & Native vegetation in natural succession with a height of less than $5 \mathrm{~m}$ \\
\hline Intervened secondary forest & ISF & $\begin{array}{l}\text { Native disturbed forest (partial logging or emergent tree removal, non-timber forest, } \\
\text { harvesting and/or hunting) }\end{array}$ \\
\hline High tree density pasture & PHD & $\begin{array}{l}\text { Pasture dominated by introduced or improved grass species with high vigor and } \\
\text { productivity, the existing trees are mature, with a tree density of more than } 30 \text { adult } \\
\text { trees per hectare }\end{array}$ \\
\hline Low tree density pasture & PLD & $\begin{array}{l}\text { Area dominated by natural or naturalized grass species, trees with } \mathrm{DBH} \text { greater than } \\
5 \mathrm{~cm} \text { and height greater than } 2 \mathrm{~m}\end{array}$ \\
\hline Degraded pasture & DP & $\begin{array}{l}\text { Pasture with less than } 50 \% \text { pasture and/or forage coverage, minimum presence of trees } \\
\text { and shrubs; with obvious signs of erosion }\end{array}$ \\
\hline
\end{tabular}

DBH diameter at breast height 




Fig. 1 Experimental design in each one of the 20 sampling areas. In the center, three sampling pits, one in each of the selected points following the slope, with two small pits on each side for SOC sampling. On the right, circular plots in each

$\mathrm{S}=\alpha \ln \left(1+\frac{\mathrm{N}}{\alpha}\right)$

where $\mathrm{S}$ is the number of species, $\mathrm{N}$ is the number of individuals and $\alpha$ is Fisher's alpha diversity index.

\section{Aboveground tree biomass and belowground} biomass

In our study, the aboveground tree biomass of each land use was estimated using the allometric models described in Table 2. With respect to ISF, a model developed by Brown (1997) for tropical moist regions with trees having a DBH between 5 and $148 \mathrm{~cm}$ was applied. For pasture with trees (DP, PLD, PHD) and SL, a model developed in Matiguás (Ruiz et al. 2004) was selected. Due to the fact that the analysis of tree roots, which constitute the belowground biomass (BGB), is a destructive and extremely expensive pastureland replicate, centered on each main pit for ecological characterization of pastureland. On the left rectangular plots in each shrub or forest replicates for ecological characterization

method, a model proposed by the IPCC was applied to estimate fine roots (Buendia et al. 2006) and a value of $30 \%$ of the aboveground biomass (AGB) was used for coarse roots (Brown 2002). To calculate the carbon, AGB and BGB were multiplied by 0.42 , following Amézquita (2004).

\section{Soil organic carbon}

For the estimation of soil organic carbon, samples were taken from each of the three principal trial pits at four different depths: 0-10, 10-20, 20-40 and 40-100 cm, giving 12 samples for each sampling plot. Subsequently the corresponding samples from the same depth of the three pits of in each plot were combined and homogenized to give a composite sample. That gave a total of 4 samples per plot; 16 samples per land use and 80 samples altogether. The

Table 2 Allometric equations used to estimate the tree aboveground and fine roots biomass on TSPS

\begin{tabular}{lll}
\hline Land uses & Allometric equation & $\mathrm{R}^{2}$ \\
\hline ISF & $\mathrm{B}=\exp \left(-2.134+2.53 \ln (\mathrm{DBH})^{2}\right)$ & 0.97 \\
DP, PLD, PHD, SL & $\log \mathrm{B}=-2.18+0.08 \cdot \mathrm{DBH}-0.0006 \cdot(\mathrm{DBH})^{2}$ & 0.94 \\
Fine Roots & $\mathrm{Y}=\exp [-1.0587+0.8836 \ln (\mathrm{AGB})]$ & 0.84 \\
\hline
\end{tabular}

$B$ biomass, $I S F$ intervened secondary forests, $D P$ degraded pasture, $P L D$ pasture with low tree density, $P H D$ pasture with high tree density, $S L$ shrubland; $A G B$ aboveground biomass, $Y$ fine roots biomass 
organic carbon concentration was determined in the laboratory by the Walkley and Black method. The total soil organic carbon (TSOC) stored in a depth of $1 \mathrm{~m}$ was calculated as the sum of SOC in each layer.

The carbon contents of each component (above and belowground biomass and TSOC) were summed to give the total carbon storage for the entire system.

\section{Statistical analysis}

For the statistical analysis of the ecological structure, aboveground and belowground biomass and carbon storage on the five land uses, nonparametric statistics (Kruskal-Wallis test) were carried out to test whether the observed differences were significant $(\mathrm{P}<0.05)$. All analyses were performed with the statistical software package InfoStat. For the estimation of richness and the diversity indices (Margalef and Fisher alpha), the software package PAleontological STatistics (PAST) was used. The calculations were carried out using the R package Vegan (Oksanen et al. 2014).

\section{Results}

Ecological structure of the five silvopastoral land uses

Out of the five land uses evaluated, SL had the highest number of species (33). Significant differences for tree density and basal area between DP and three land uses (SL, ISF, and PHD) were found. PHD had the highest basal area followed by ISF and SL (Table 3), whereas DP had the lowest. To estimate species richness and diversity the Margalef index was used, with SL having significantly higher values than the other uses. Similarly, the values of Fisher's alpha index show that there is a significantly different diversity of species for SL compared with the other land uses (Table 3).

Individual rarefaction curves were calculated to compare the species richness and support the result of the richness and diversity indices. Unlike the Margalef and Fisher indices, the rarefaction curves suggest that not only SL but also ISF differ from the other land uses in terms of richness (Fig. 2).
Carbon content in the aboveground and belowground biomass

Estimates of carbon storage in the aboveground tree biomass (Fig. 3) show that ISF $\left(8.4 \mathrm{t} \mathrm{C} \mathrm{ha}^{-1}\right)$ and PHD (6.3 $\left.\mathrm{t} \mathrm{C} \mathrm{ha}^{-1}\right)$ accumulate the most $\mathrm{C}$. On the other hand, DP $\left(1.2 \mathrm{t} \mathrm{C} \mathrm{ha}^{-1}\right)$ had the lowest storage of C. The land uses SL and PLD had values between these two extremes and there were no significant differences between them. The carbon content in fine and coarse roots followed the same pattern (Fig. 3). For both above and belowground biomass carbon, significant differences were found between DP and ISF, whilst the other land uses had no statistical differences between them $(\mathrm{P}>0.05)$. With regards to the total carbon stored in the biomass, DP had the lowest amount of total carbon $\left(1.9 \mathrm{t} \mathrm{C} \mathrm{ha}^{-1}\right)$, while ISF had the highest value (13.2 $\left.\mathrm{t} \mathrm{C} \mathrm{ha}^{-1}\right)$, followed by PHD (9.8 t C ha-1) (Fig. 3).

Soil organic carbon

Soil organic carbon (SOC) content per layer is shown in Fig. 4. In the 0-10 cm layer, SOC ranged from 23.2 to $35.2 \mathrm{t} \mathrm{C} \mathrm{ha}^{-1}$ but no significant differences were found between land uses. The $\mathrm{C}$ content varied significantly in the $10-20 \mathrm{~cm}$ layer, ranging from 12.6 to $29.1 \mathrm{t} \mathrm{C} \mathrm{ha}^{-1}$ for DP and SL, respectively. In the deeper soil layers (20-40 and 40-100 cm) ISF had the highest values (38.7 and $65.4 \mathrm{t} \mathrm{C} \mathrm{ha}^{-1}$, respectively). Degraded pasture had the lowest values in all four soil layers, but was only significantly different from ISF in the 10-20, 20-40 and 40-100 cm layers. The others land uses had no significant differences between them (Fig. 4).

With regards to the TSOC, significant differences were found between land uses. Intervened secondary forests had the largest values $\left(163.6 \mathrm{t} \mathrm{C} \mathrm{ha}^{-1}\right)$, followed by SL $\left(122.2 \mathrm{t} \mathrm{C} \mathrm{ha}^{-1}\right)$, both of which were significantly larger than DP $\left(76.9 \mathrm{t} \mathrm{C} \mathrm{ha}^{-1}\right)$, which had the lowest values. PLD (109.5 $\left.\mathrm{t} \mathrm{C} \mathrm{ha}^{-1}\right)$ and PHD (108.1 t C ha ${ }^{-1}$ ) had similar carbon contents and were not significantly different from the other land uses.

\section{Total carbon}

The estimation of total carbon, ranged from 79.4 to $171 \mathrm{t} \mathrm{C} \mathrm{ha}^{-1}$ for DP and ISF, respectively. The SOC was the largest contributor to the carbon stock in all 
Table 3 Ecological structure of the five land uses studied

\begin{tabular}{llclll}
\hline LULC & \# Sp & Tree density $\left(\mathrm{n} \mathrm{ha}^{-1}\right)$ & BA $\left(\mathrm{m}^{2} \mathrm{ha}^{-1}\right)$ & \multicolumn{2}{l}{ Richness and diversity } \\
\cline { 4 - 6 } & & & Margalef & $3,1(0.12) \mathrm{b}$ & $5.0(0.29) \mathrm{b}$ \\
$\mathrm{SL}$ & 33 & $75.0(51.77) \mathrm{b}$ & $2.05(0.66) \mathrm{b}$ & $2.3(0.24) \mathrm{a}$ & $3.0(0.43) \mathrm{a}$ \\
$\mathrm{ISF}$ & 26 & $82.7(30.45) \mathrm{b}$ & $2.20(0.65) \mathrm{b}$ & $2.2(0.13) \mathrm{a}$ & $3.3(0.28) \mathrm{a}$ \\
PHD & 19 & $105.9(53.22) \mathrm{b}$ & $2.35(1.88) \mathrm{b}$ & $2.2(0.09) \mathrm{a}$ & $3.3(0.32) \mathrm{a}$ \\
PLD & 19 & $24.7(26.81) \mathrm{ab}$ & $1.25(0.34) \mathrm{ab}$ & $2.1(0.13) \mathrm{a}$ & $3.1(0.22) \mathrm{a}$ \\
DP & 20 & $24.3(6.58) \mathrm{a}$ & $0.55(0.16) \mathrm{a}$ & &
\end{tabular}

Medians (standard error) within a column with different letters are significantly different $(\mathrm{P}<0.05)$

$S p$ species, $B A$ basal area, $S L$ shrubland, $I S F$ intervened secondary forests, $P H D$ pasture with high tree density, $P L D$ pasture with low tree density, $D P$ degraded pasture

Fig. 2 Individual rarefaction curves of the five land uses studied: $S L$ Shrubland, ISF intervened secondary forests, $P H D$ pasture with high tree density, $P L D$ pasture with low tree density, $D P$ degraded pasture

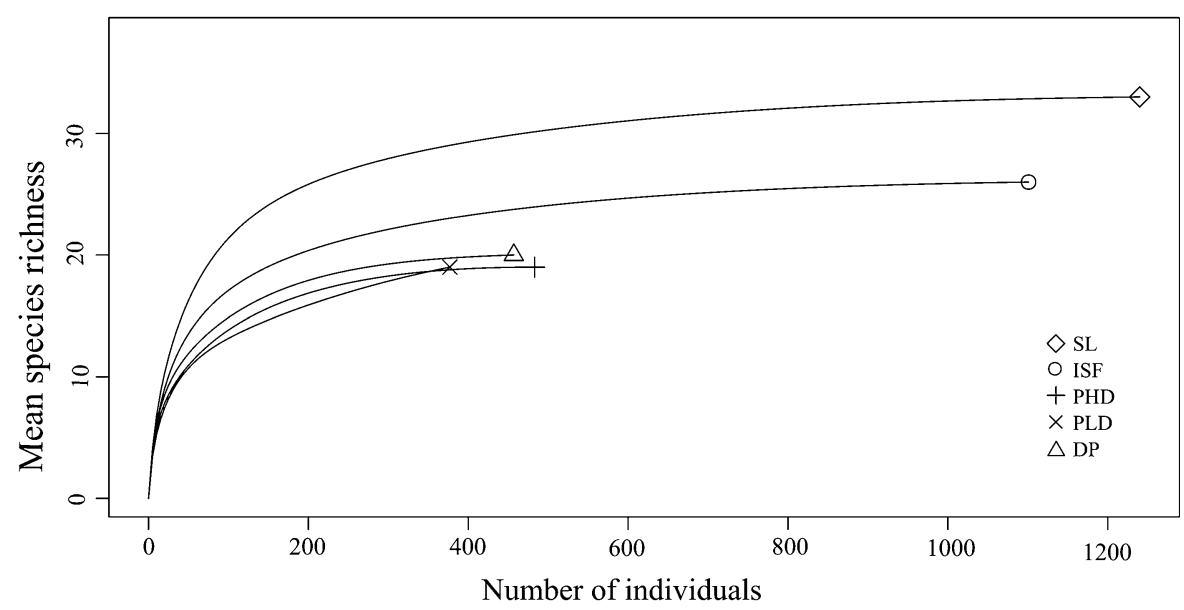

land uses studied ranging from 91 to $98 \%$ of the total C (Fig. 5).

\section{Discussion and conclusion}

The findings of this study show that, although PLD, DP and PHD have continuous grazing activity, they retain a considerable number of trees, particularly in the case of PHD. These trees are remnants of forest or the product of tree selection by farmers, driven by different interests (Harvey et al. 2011). In spite of this, these land uses have a considerable degree of richness, contributing to preserve tree diversity in agricultural landscapes (Gordon et al. 2004). It should be noted that the higher density of trees in PHD does not translate into greater diversity than in PLD and DP, suggesting that many of the trees present in PHD belong to the same tree species. This abundance of trees in PHD benefits animal welfare because of the shade provided by tree cover (Betancourt et al. 2003).

Of the three land uses with highest BA and tree density (SL, ISF and PHD), SL has a substantially higher diversity value, if we consider the Margalef and Fisher's alpha values, suggesting that in the process of natural succession there is a recovery of diversity. It should be mentioned that in livestock landscape areas, SL has a relatively high tree diversity which could be related to the favorable climate conditions and nonintervention during the rainy season, allowing the growth of seedlings, fodder tree, leguminous and nonleguminous species, inter alia (Shelton 2000). However, dynamics change in the dry season, when forage availability is reduced and woody vegetation becomes an important source for cattle feeding (Dagang and Nair 2003), which represents an economical value for SL, but also a threat for its diversity. Contrary to expectations, the Margalef and Fisher's alpha indices 


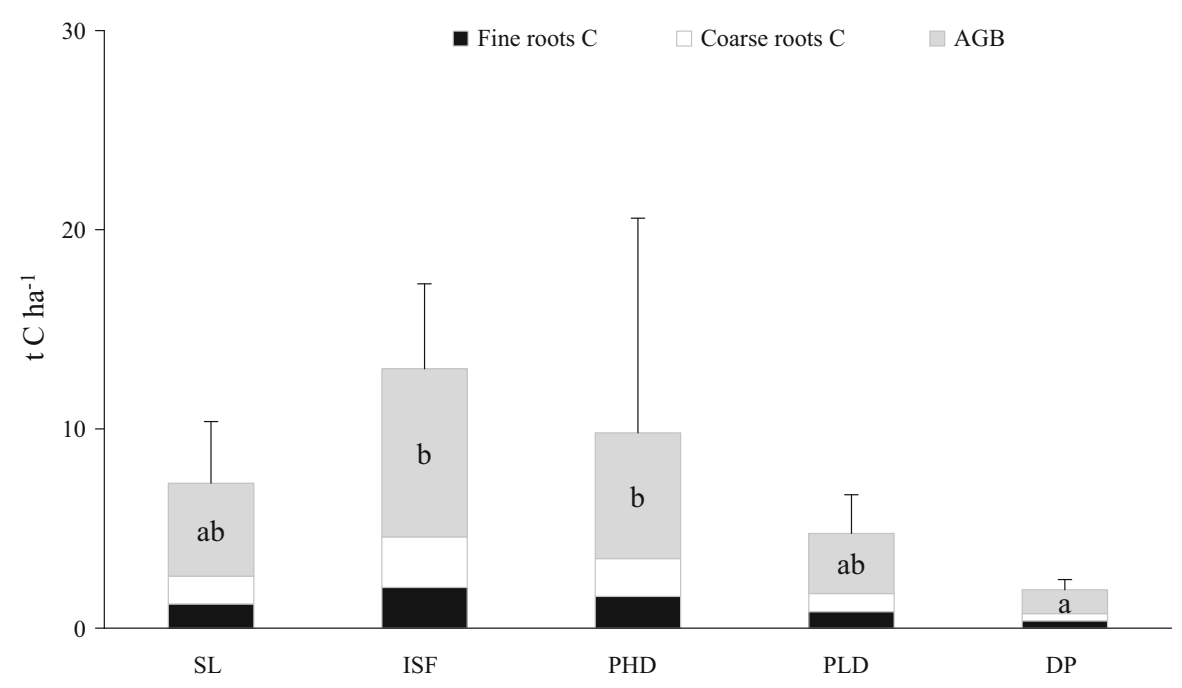

Fig. 3 Median carbon contents of the aboveground biomass (AGB) and belowground biomass (BGB) (coarse and fine roots) for five different land use classes: $S L$ Shrubland, $I S F$ intervened secondary forests, $P H D$ pasture with high tree density, $P L D$

pasture with low tree density, $D P$ degraded pasture. Error bars correspond to standard errors of the medians; different letters indicate statistical differences among LULC $(\mathrm{P}<0.05)$
Fig. 4 Median soil organic carbon content for the five different land use classes: $S L$ Shrubland, ISF intervened secondary forests, $P H D$ pasture with high tree density, $P L D$ pasture with low tree density, $D P$ degraded pasture, at four depths 0-10, 10-20, 20-40, $40-100 \mathrm{~cm}$. Error bars show the standard errors; different letters indicate statistical differences among LULC $(\mathrm{P}<0.05)$

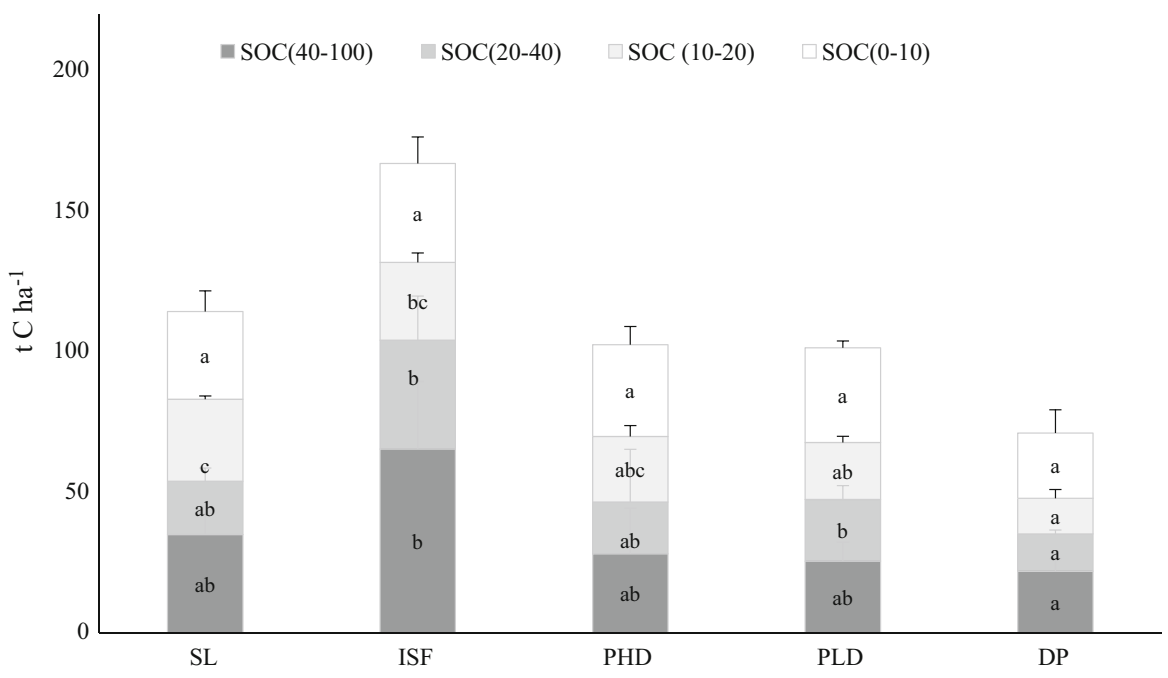

reported for pastures with trees in the area: values between 8.2 and $17.5 \mathrm{t} \mathrm{C}^{-1}$ (Ruiz et al. 2004), or, between 1.2 and $19.1 \mathrm{t} \mathrm{C}^{-1}$ reported by ChacónLeón and Harvey (2013; values AGB multiplied by 0.42). For ISF, Ibrahim et al. (2007) found values of $23 \mathrm{t} \mathrm{C} \mathrm{ha}^{-1}$ in Nicaragua (humid tropical forest), much lower than those found for the same land use in Costa Rica (90.8 $\mathrm{t} \mathrm{C} \mathrm{ha}^{-1}$, annual $\mathrm{T}=27.2{ }^{\circ} \mathrm{C}$; annual $\mathrm{P}=2043 \mathrm{~mm}$; sub-humid tropical forest). Kirby and Potvin (2007) reported values of $75 \mathrm{t} \mathrm{C} \mathrm{ha}^{-1}$ (AGB) in agroforest uses in Panamá for aboveground carbon are consistent with data 
Fig. 5 Total carbon storage in the biomass (TBC) and in the soil down to a depth of $100 \mathrm{~cm}$ (TSOC) for the different land uses. $S L$ Shrubland, ISF intervened secondary forests, $P H D$ pasture with high tree density, $P L D$ pasture with low tree density, $D P$ degraded pasture, Different letters indicate significant differences $(\mathrm{P}<0.05)$; error bars show the standard errors of the total carbon

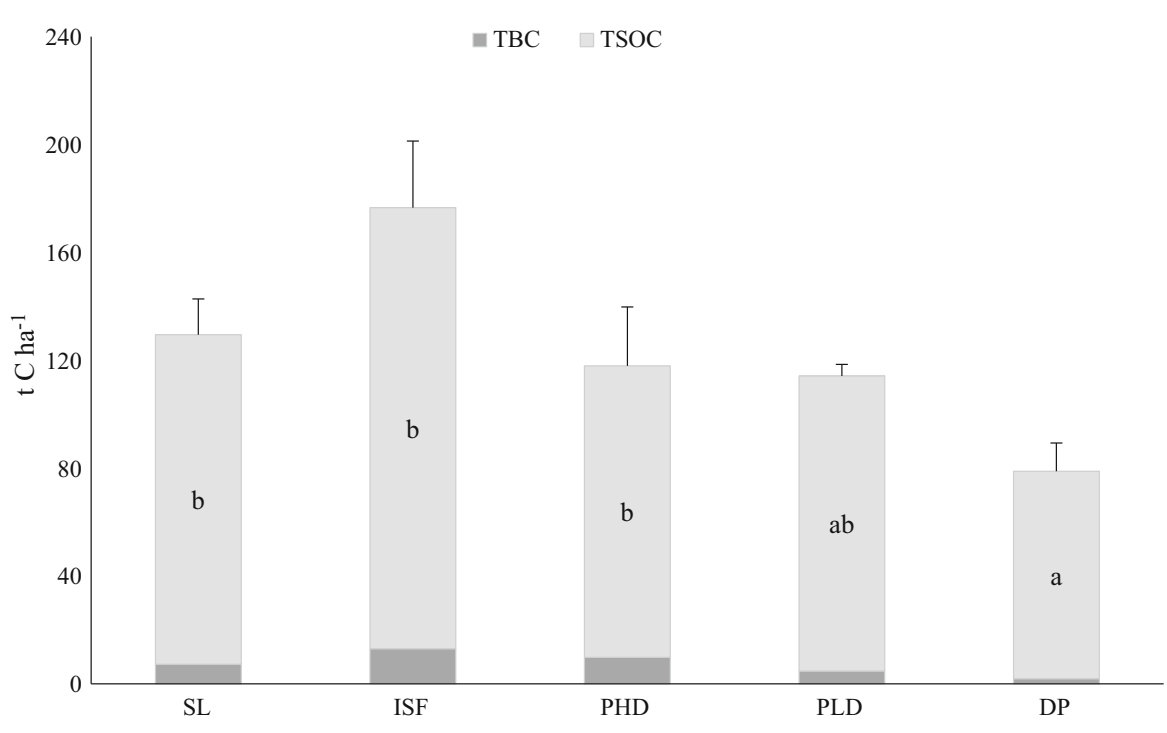

(annual $\mathrm{T}=26{ }^{\circ} \mathrm{C}$; annual $\mathrm{P}=2500 \mathrm{~mm}$; tropical moist forest) similar to those found in Costa Rica. Many factors as climate variations, soil type, or age, may contribute to explain this variability, but if part of the difference is due to management, then, ISF shows a remarkable $\mathrm{C}$ sequestration potential with the appropriate management.

The values of TSOC in our study (76-163.6 $\mathrm{t} \mathrm{C} \mathrm{ha}^{-1}$ ) at $1 \mathrm{~m}$ depth agree with various studies. For example, Amézquita et al. (2010) found values between 95 and $181 \mathrm{t} \mathrm{C} \mathrm{ha}^{-1}$ in Pocora, a subhumid zone of Costa Rica. In Venezuela, Delaney et al. (1997) found a wide range of values (125-257 $\mathrm{t} \mathrm{C} \mathrm{ha}^{-1}$ ) for forests, with $125 \mathrm{t} \mathrm{C} \mathrm{ha}^{-1}$ corresponding to dry forests in conditions similar to those of this study. Our results also agree with those of Andrade et al. (2008) who found an average value of $110 \mathrm{t} \mathrm{C} \mathrm{ha}^{-1}$ (down to $0.6 \mathrm{~m}$ ) in Guanacaste (Costa Rica). However, other studies report higher values if we only take into account what is stored in the upper layers (Ruiz et al. 2004; McGroddy et al. 2015).

With respect to the vertical distribution of SOC, more than 50\% is accumulated in the top $20 \mathrm{~cm}$ of the soil in all land uses except ISF, which has less than $40 \%$ of the total in this layer. Andrade et al. (2008) also found that more than half of the SOC accumulates in the top $20 \mathrm{~cm}$ in silvopastoral land uses, although their study only went down to a depth of $60 \mathrm{~cm}$. In the top $20 \mathrm{~cm}$ there were relatively few differences between the five land uses. However, below $20 \mathrm{~cm}$, ISF starts to accumulate more SOC than the other land uses, resulting in a higher total value at $1 \mathrm{~m}$. Thus, TSOC in ISF is double that of DP down to $1 \mathrm{~m}$. In agreement with Takimoto et al. (2008), it is advisable to carry out SOC studies to a standard depth of $1 \mathrm{~m}$, since smaller depths can give erroneous results.

The largest storage of TSOC found in ISF (163.6 $\mathrm{t} \mathrm{C} \mathrm{ha}^{-1}$ ) agrees with some studies but not with others. The comparison is difficult because land uses do not always coincide. For instance, Amézquita et al. (2004) found that a secondary forest in Colombia stored more TSOC $\left(152 \mathrm{t} \mathrm{C} \mathrm{ha}^{-1}\right)$ than a degraded pasture $\left(97 \mathrm{t} \mathrm{C} \mathrm{ha}^{-1}\right)$ and a mixed forage bank $\left(86 \mathrm{t} \mathrm{C} \mathrm{ha}^{-1}\right)$. However, the same authors found no differences between land uses for TSOC in Esparza (Costa Rica) and furthermore, the values tended to be lower in a secondary forest $\left(116 \mathrm{t} \mathrm{Cha}^{-1}\right)$ than in a silvopastoral system $\left(130 \mathrm{t} \mathrm{C} \mathrm{ha}^{-1}\right)$. Kirby and Potvin (2007) found no differences between forest, agroforestry and pasture but their study only went down to a depth of $40 \mathrm{~cm}$. Ruiz et al. (2004) found no differences between shrubland and native pasture or improved pasture with trees (SOC to $60 \mathrm{~cm}$ depth). In these previous studies, the quantification of SOC to a shallower depth may explain the lack of differences. On the other hand, the relatively similar values of TSOC found for the three types of silvopastoral systems (PHD, PLD and DP) is surprising since one would expect an increase in SOC with increasing tree density and basal area. McGroddy et al. (2015) also found no relationship between SOC content and tree density or biomass. The lack of significant differences 
between DP, PLD and PHD, and the fact that the values are relatively high, suggests that logging may have occurred recently and that the present SOC content still reflects previous land use (Mosquera et al. 2012). This may have been favored by the protection that the high clay content of these soils provides to SOC (Takimoto et al. 2008).

Soil organic carbon was the largest pool of total carbon for all the land uses studies, which agrees with other studies (Ruiz et al. 2004; McGroddy et al. 2015; Takimoto et al. 2008). While in our study the contribution by TSOC does not fall below $90 \%$, other studies have found differences depending on land use. Amézquita et al. (2010) report values of $62 \%$ in native forests, $90 \%$ in silvopastoral systems and $95-98 \%$ in pastures. However, Kirby and Potvin (2007) found values of $90 \%$ in pastures but only $13 \%$ in forests and $31 \%$ in agroforestry systems. The fact that the latter study only went down to $40 \mathrm{~cm}$ could mean that they underestimated the $\mathrm{C}$ of the soils in the forest and agroforestry land uses and, therefore, underestimated its contribution to the total. Again, this emphasizes the importance of normalizing the study depth for SOC.

In our study, we explored the links between biodiversity and $\mathrm{C}$ storage but we did not find any evidence of relationships between tree diversity and biomass $\mathrm{C}$ storage or SOC. The higher tree diversity in SL did not translate into a higher C storage, despite the fact that some studies highlight the benefits of complementing species (Lasky et al. 2014; Saha et al. 2009). Our result is in agreement with Kirby and Potvin (2007) who attributed the lack of relationship between diversity and SOC to the high soil variability. Since SL is a land use in transition, in our case it is also unlikely that diversity is related to SOC due to the fact that changes in soil C occur slowly, particularly in clayey soils and SOC, therefore, still reflects previous land uses. Since the connection between biodiversity and $\mathrm{C}$ storage still seems unclear, new studies would be necessary to confirm or reject this relationship.

The higher storage of total C in ISF, SL and PHD compared with DP indicates that deforestation, even when leaving a certain number of trees per ha (like in DP), results in a considerable loss of $\mathrm{C}$ and, therefore, greenhouse gas emissions. Although highly variable, the results suggest that increasing tree cover in degraded pastures would tend to increase carbon storage by $40 \%$, in addition to other benefits. Thus, through appropriate management, degraded pastures have a high potential for carbon sequestration, even more if we consider that this degraded land use occupies a significant part of the region (Szott et al. 2000).

In conclusion, under the climatic conditions of Matiguás, the change of land use from ISF to pastures, especially those with low tree densities, means a loss of $\mathrm{C}$ storage. However, because of the importance that livestock activities have in most tropical areas, traditional silvopastoral systems are a preferable alternative to extensive cattle ranching from an economic and environmental point of view. The recovery of deforested areas can be boosted through the implementation of production systems that are applied and executed by the stakeholders.

The enhancement of the landscape matrix in livestock areas through TSPS has the potential to provide many benefits. Not only direct financial benefits for the farmer, but also global benefits as a result of improvements to soil and water quality, carbon storage in soil and aboveground biomass, linkage of isolated forest patches, the provision of habitats for wildlife and increases in biodiversity among other things. Since the systems are so complex, it is necessary to do more targeted research to better understand each of the interactions, contributions and linkages between the components. Of special relevance is the study of $\mathrm{C}$ storage in the soil due to its large contribution to the total carbon. It is, therefore, important that it is quantified to a sufficient depth to show the differences between land uses. We suggest a depth of $1 \mathrm{~m}$.

Acknowledgements This study was carried out in the context of the Regional Integrated Silvopastoral Approaches to Ecosystem Management Project (RISEMP) pilot, 2002-2008, in Colombia, Costa Rica and Nicaragua.

\section{References}

Amézquita MC, Ibrahim M, Llanderal T, Buurman P, Amézquita E (2004) Carbon sequestration in pastures, silvopastoral systems and forests in four regions of the Latin American tropics. J Sustain For 21(1):31-49

Andrade HJ, Ibrahim M (2003) ¿Cómo monitorear el secuestro de carbono en los sistemas silvopastoriles? Agrofor Am 10(39-40):109-116

Andrade HJ, Brook R, Ibrahim M (2008) Growth, production and carbon sequestration of silvopastoral systems with 
native timber species in the dry lowlands of Costa Rica. Plant Soil 308(1-2):11-22

Bennetzen EH, Smith P, Porter JR (2016) Decoupling of greenhouse gas emissions from global agricultural production: 1970-2050. Glob Change Biol 22(2):763-781

Betancourt K, Ibrahim M, Harvey C, Vargas B (2003) Efecto de la cobertura arbórea sobre el comportamiento animal en fincas ganaderas de doble propósito en Matiguás, Matagalpa, Nicaragua. Agrofor Am 10(39-40):47-51

Brown S (1997) Estimating biomass and biomass change of tropical forests: a primer, vol 134. Food \& Agriculture Organisation of the United Nations, Rome

Brown S (2002) Measuring, monitoring, and verification of carbon benefits for forest-based projects. Philos Trans R Soc Lond A 360(1797):1669-1683

Buendia L, Miwa K, Ngara T, Tanabe K (2006) IPCC guidelines for National Greenhouse Gas Inventories. Prepared by the National Greenhouse Gas Inventories Programme. IGES, Hayama

Carr D, Barbieri A, Pan W, Iranavi H (2006) Agricultural change and limits to deforestation in Central America. In: Agriculture and climate beyond 2015, pp 91-107

Chacón-León M, Harvey CA (2013) Reservas de biomasa de árboles dispersos en potreros y mitigación al cambio climático. Agron Mesoam 24(1):17-26

Charturvedi RK, Raghubanshi AS, Singh JS (2011) Carbon density and accumulation in woody species of tropical dry forest in India. For Ecol Manage 262:1576-1588

Dagang AB, Nair PKR (2003) Silvopastoral research and adoption in Central America: recent findings and recommendations for future directions. Agrofor Syst 59(2):149-155

Delaney M, Brown S, Lugo AE, Torres-Lezama A, Quintero NB (1997) The distribution of organic carbon in major components of forests located in five life zones of Venezuela. J Trop Ecol 13(05):697-708

FAO (Food and Agriculture Organization of the United Nations) (2001) Global Forest Resources Assessment 2000. FAO Forestry Paper No. 140. Rome

Fisher RA, Corbet AS, Williams CB (1943) The relation between the number of species and the number of individuals in a random sample of an animal population. J Anim Ecol 12(1):42-58

Gibbs H, Ruesch, AS, Foley JA, Ramankutty N, Achard F, Holmgren P (2010) Pathways of agricultural expansion across the tropics: Implications for forest resources. Proc Natl Acad Sci USA (forthcoming)

Gordon JE, Hawthorne WD, Reyes-Garcia A, Sandoval G, Barrance AJ (2004) Assessing landscapes: a case study of tree and shrub diversity in the seasonally dry tropical forests of Oaxaca, Mexico and southern Honduras. Biol Conserv 117(4):429-442

Graesser J, Aide TM, Grau HR, Ramankutty N (2015) Cropland/pastureland dynamics and the slowdown of deforestation in Latin America. Environ Res Lett 10(3):034017

Harvey CA, Villanueva C, Esquivel H, Gómez R, Ibrahim M, Lopez M, Martinez J, Muñoz D, Restrepo C, Saénz JC, Villacís J, Sinclair FL (2011) Conservation value of dispersed tree cover threatened by pasture management. For Ecol Manage 261(10):1664-1674
Ibrahim M, Chacón M, Cuartas C, Naranjo J, Ponce G, Vega P, Rojas J (2007 Almacenamiento de carbono en el suelo y la biomasa arbórea en sistemas de usos de la tierra en paisajes ganaderos de Colombia, Costa Rica y Nicaragua. Agroforestería en las Américas, $\mathrm{N}^{\circ} 45$

IPCC (2000) In: Watson RT, Noble IR, Bolin B, Ravindranath NH, Verardo DJ, Dokken DJ (eds) Land use, land-use change and forestry. Cambridge University Press, Cambridge

IPCC (2007) Climate Change 2007: the physical science basis. Contribution of Working Group I to the Fourth Assessment Report of the Intergovernmental Panel on Climate Change [Solomon S, Qin D, Manning M, Chen Z, Marquis M, Averyt KB, Tignor M, Miller HL (eds)]. Cambridge University Press, Cambridge, United Kingdom and New York, NY, USA

Jose S (2009) Agroforestry for ecosystem services and environmental benefits: an overview. Agrofor Syst 76(1):1-10

Kaimowitz D (1996) Livestock and deforestation in Central America in the 1980s and 1990s: a policy perspective (No. 9). Cifor

Keenan RJ, Reams GA, Achard F, de Freitas JV, Grainger A, Lindquist E (2015) Dynamics of global forest area: results from the FAO global forest resources assessment 2015. For Ecol Manage 352:9-20

Kirby KR, Potvin C (2007) Variation in carbon storage among tree species: implications for the management of a smallscale carbon sink project. For Ecol Manage 246(2):208-221

Kottek M, Grieser J, Beck C, Rudolf B, Rubel F (2006) World map of the Köppen-Geiger climate classification updated. Meteorol Z 15(3):259-263

Krebs CJ (1989) Ecological methodology (No. QH541. 15. S72. K74 1999.). Harper \& Row, New York

Lasky JR, Uriarte M, Boukili VK, Erickson DL, John Kress W, Chazdon RL (2014) The relationship between tree biodiversity and biomass dynamics changes with tropical forest succession. Ecol Lett 17(9):1158-1167

Levard L, Marín López Y, Navarro I (2001) Municipio de Matiguás: Potencialidades y limitantes del desarrollo agropecuario

MacDicken KG (1997) A guide to monitoring carbon storage in forestry and agroforestry projects. Winrock International Institute for Agricultural Development, Little Rock

Magurran AE (1981) Biological diversity and woodland management: an investigation with special reference to Banagher, Co. Derry, N. Ireland (Doctoral dissertation, New University of Ulster)

Margalef R (1958) Information theory in ecology. Gen Syst 3:36-71

McGroddy ME, Lerner AM, Burbano DV, Schneider LC, Rudel TK (2015) Carbon stocks in silvopastoral systems: a study from four communities in southeastern Ecuador. Biotropica 47(4):407-415

Montagnini F, Ibrahim M, Murgueitio E (2013) Silvopastoral systems and climate change mitigation in Latin America. Bois et Forêts des Tropiques 316(2):3-16

Mosquera O, Buurman P, Ramirez BL, Amezquita MC (2012) Carbon stocks and dynamics under improved tropical pasture and silvopastoral systems in Colombian Amazonia. Geoderma 189:81-86 
Oksanen J, Blanchet FG, Kindt R, Legendre P, Minchin PR, O'Hara RB, Wagner H (2014) vegan: Community Ecology Package. R package version 2.1-41/r2867

Pagiola S, Ramírez E, Gobbi J, de Haan C, Ibrahim M, Murgueitio E, Ruíz JP (2007) Paying for the Environmental Services of Silvopastoral Practices in Nicaragua. Ecol Econ 64(2):374-385. https://doi.org/10.1016/j.ecolecon. 2007.04.014

Ruiz A, Ibrahim M, Beer J, Locatelli B, Andrade Castañeda HJ (2004) Fijación y almacenamiento de carbono en sistemas silvopastoriles y competitividad económica de fincas ganaderas en Matiguás, Nicaragua

Saha SK, Nair PR, Nair VD, Kumar BM (2009) Soil carbon stock in relation to plant diversity of homegardens in Kerala, India. Agrofor Syst 76(1):53-65

Segura M, Kanninen M (2002) Inventario para estimar carbono en ecosistemas forestales tropicales. Inventarios Forestales para Bosques Latifoliados en América Central. Turrialba, CR, CATIE, pp 202-216

Shelton M (2000) Tropical forage tree legumes: Key development issues http://www.fao.org/ag/AGP/AGPC/doc/
Present/Shelton/. A short version of this paper has been included in Unasylva 51 (200), 25-32

Szott L, Ibrahim M, Beer J (2000) The hamburger connection hangover: cattle, pasture land degradation and alternative land use in Central America (No. 313). Bib. Orton IICA/ CATIE

Takimoto A, Nair PR, Nair VD (2008) Carbon stock and sequestration potential of traditional and improved agroforestry systems in the West African Sahel. Agr Ecosyst Environ 125(1):159-166

West PC, Gibbs HK, Monfreda C, Wagner J, Barford CC, Carpenter SR, Foley JA (2010) Trading carbon for food: global comparison of carbon stocks vs. crop yields on agricultural land. Proc Natl Acad Sci USA 107(46):19645-19648

Yamamoto W, ApDewi I, Ibrahim M (2007) Effects of silvopastoral areas on milk production at dual-purpose cattle farms at the semi-humid old agricultural frontier in central Nicaragua. Agric Syst 94(2):368-375 